\title{
Geochemistry of ultramafic xenoliths in Cenozoic alkali basalts from Jiangsu province, eastern China and their geological implication
}

\author{
Shao-Wei Huang ${ }^{1}$, Yung-Tan Lee ${ }^{1,2, *}$, Ju-Chin Chen ${ }^{1}$, Kung-Suan Ho ${ }^{3}$, \\ Meng-Lung Lin ${ }^{2}$, Yen-Tsui Hu ${ }^{4}$ and Ren-Yi Huang ${ }^{5}$ \\ ${ }^{1}$ Institute of Oceanography, National Taiwan University, Taipei 106, Taiwan. \\ ${ }^{2}$ Department of Tourism, Aletheia University, Tamsui 25103, Taiwan. \\ ${ }^{3}$ National Museum of Natural Science, Taichung 404, Taiwan. \\ ${ }^{4}$ Sinotech Engineering Consultants Inc., Taipei 114, Taiwan. \\ ${ }^{5}$ Department of Leisure Business Management, DeLin Institute of Technology, Taipei 236, Taiwan. \\ ${ }^{*}$ Corresponding author.e-mail: au4300@mail.au.edu.tw
}

\begin{abstract}
Twelve ultramafic xenoliths in Cenozoic alkali basalts from Jiangsu province, eastern China have been analyzed for major, trace, $\mathrm{Sr}-\mathrm{Nd}$ isotopic composition and mineral chemical compositions and the origin of these ultramafic xenoliths is discussed based on the geochemical constraints. Based on classification norms, the ultramafic xenoliths in the present study belong to type I xenolith. The Fo-values of the ultramafic xenoliths range from 90.18 to 92.18 . The ultramafic xenoliths have higher $\mathrm{MgO}$ content, but lower $\mathrm{Al}_{2} \mathrm{O}_{3}, \mathrm{TiO}_{2}, \mathrm{CaO}$ and $\mathrm{Na}_{2} \mathrm{O}$ contents than those of primitive mantle, indicating that they represent residues formed by different degrees of partial melting from the upper mantle. The enrichment of Rb, $\mathrm{Ba}, \mathrm{U}, \mathrm{Nb}, \mathrm{K}, \mathrm{La}, \mathrm{Ce}, \mathrm{Sr}, \mathrm{P}$ and $\mathrm{Zr}$ of ultramafic xenoliths found in Jiangsu province, eastern China may be related to the $\mathrm{CO}_{2}-\mathrm{H}_{2} \mathrm{O}$-fluids metasomatism. On the basis of $\mathrm{Sr}-\mathrm{Nd}$ isotopic ratios, we suggest that the lithospheric mantle beneath the study area mostly belongs to depleted-type mantle but with slightly enriched signatures, indicating the heterogeneous characteristics in the mantle source and the influence of different degrees of fluids-metasomatism on the mantle composition. The equilibrium $\mathrm{P}-\mathrm{T}$ conditions of the spinel lherzolite xenoliths are: $\mathrm{T}=913 \sim 1045^{\circ} \mathrm{C}, \mathrm{P}=13 \sim 22 \mathrm{~kb}$ corresponding to depths of 45-83 km. The $\mathrm{P}-\mathrm{T}$ conditions suggest that the geothermal gradient of the upper mantle beneath the study area is approximately similar to oceanic geotherm which may be caused by asthenosphere upwelling. We suggested that lithospheric mantle thinning accompanied by asthenosphere upwelling has occurred and a newly accreted and cooled asthenospheric mantle may exist beneath the study area.
\end{abstract}

\section{Introduction}

Most xenoliths can be used to estimate the pressures and temperatures of formation in terms of available experimental data. These temperature and pressure estimates from ultramafic xenoliths may provide important information on the thermal and dynamic evolution of their lithospheric source region. The ultramafic xenoliths found in Panshishan area, Jiangsu province (figure 1) were situated in the boundary of Yangtze Craton and southeastern edge of Sino-Korean Craton, is one of the oldest Archean continental nuclei in the world (Jahn et al. 1987; Jahn 1990; Liu et al. 1992;

Keywords. Ultramafic xenoliths; geochemistry; metasomatism; Jiangsu province. 


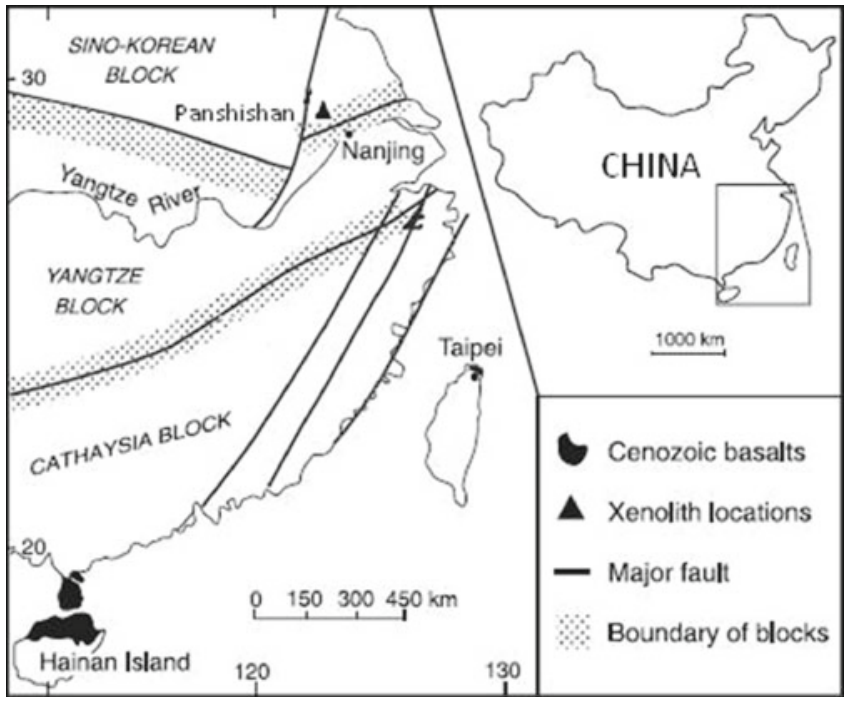

Figure 1. Sketch map of the tectonic framework and distribution of Cenozoic basaltic rocks in SE China. Three blocks are defined, from south to north: the Cathaysia, Yangtze and Sino-Korean blocks. The Panshishan sample locality of this study is shown as a triangle.

Huang et al. 2004). Systematic studies of eastern part of the NCC demonstrated a thinner $(<80 \mathrm{~km})$ and hotter lithosphere occured in the Cenozoic (Menzies et al. 1993; Fan et al. 2000). The timing, extent and mechanisms of thinning the lithospheric mantle beneath the North China Craton are yet to be fully understood (Zhang et al. 1998; O'Reilly et al. 2001; Gao et al. 2002; Wilde et al. 2003). The research of these ultramafic xenoliths in Cenozoic alkali basalts from Jiangsu province, easten China can provide new geochemical, isotope data, mineral chemistry and $\mathrm{P}-\mathrm{T}$ data. The results may shed some light on the nearby North China Craton which is now accepted to lack the lithospheric roots and perhaps Jiangsu province, eastern China too joins it. The Sino-Korean Craton has preserved crustal remnants as old as $3800 \mathrm{Ma}$ (Liu et al. 1992), and is the largest cratonic block in China, covering an area of more than $15,00,000 \mathrm{~km}^{2}$. The Sulu ultrahigh pressure metamorphic belt caused by the collision between the Sino-Korean Craton and the Yangtze Craton in Triassic time was extrapolated as the suture of the Sino-Korean Craton and the Yangtze Craton to the east of Tanlu fault zone (Okay and Sengör 1992; Yin and Nie 1993).

Previous studies (Li 1994; Chung 1999; Huang et al. 2004; Ying et al. 2006) agree with a crustaldetachment model for the suturing of the SinoKorean Craton and the Yangtze Craton. The model mentioned above postulated the upper crust of the Yangtze Craton was detached and thrusted northward over the Sino-Korean Craton for about $400 \mathrm{~km}$, whereas the lower part of its lithospheric mantle was subducted under the Sino-Korean Craton along the subsurface suture extending eastward from Nanjing. On the basis of this model, the lower crust and the lithospheric mantle beneath the studied area may have a Sino-Korean Craton character. The Sino-Korean Craton which was extensively thinned during the Late Mesozoic and Cenozoic resulted from the replacement of old, cold and depleted lithospheric mantle by young, hot and fertile mantle (Menzies et al. 1993; Griffin et al. 1998) can be divided into the Eastern, Western Blocks and the intervening Trans-North China Orogen (TNCO) (Zhao 2001).

The lithological, geochemical, structural, metamorphic and geochronological characters are different in Eastern and Western Blocks (Zhao 2001). The spatial distribution of volcanic rocks in the study area is controlled by NNE-trending Tan-Lu fault occurred as a result of lithospheric extension. The relatively thin crust and lithosphere in eastern China may be caused by mantle upwelling which triggered partial melting of lithospheric mantle (Chung 1999; Deng et al. 2004; Lee et al. 2006). Lee et al. (2006) pointed out that basaltic rocks from Shandong province may be derived from partial melting of lithospheric mantle (MORB-like) involved a few EM1 components which may be produced by the recent $\mathrm{H}_{2} \mathrm{O}-\mathrm{CO}_{2}$ fluid metasomatism.

In recent years, several authors (Xu 2001; Guo et al. 2003; Xu et al. 2004; Zhang et al. 2006) proposed that thinning of the lithosphere beneath the North China Craton (NCC) may have occurred since the Palaeozoic, probably due to the loss of physical integrity of the craton resulted from the Triassic collision between the NCC and the Yangtze Block. The lithospheric mantle in the western SKC is relatively old compared with that beneath the eastern SKC, which may be a mixture of old lithospheric relicts and newly accreted mantle (Xu et al. 2004). When compared to the MORB source (50-250 ppm), the Cenozoic lithospheric mantle of the western part of the north craton is dominated by much lower water content (Xia et al. 2013). The low $\mathrm{H}_{2} \mathrm{O}$ content likely results from mantle reheating, possibly due to an upwelling asthenospheric flow during the late Mesozoic-early Cenozoic lithospheric thinning of the NCC (Xia et al. 2013).

In this paper, we report the major, trace elements (including rare-earth elements) and $\mathrm{Sr}-\mathrm{Nd}$ isotopic composition of ultramafic xenoliths combined with the constituent mineral chemical compositions in order to deduce the origin of these ultramafic xenoliths and the geochemical characteristics of the upper mantle as well as deep geological processes beneath Jiangsu province. 


\section{General geological settings}

The Panshishan area, Jiangsu province, eastern China (figure 2) is tectonically located in the boundary of Yangtze Craton and southeastern edge of Sino-Korean Craton, is one of the oldest Archean continental nuclei in the world (Jahn et al. 1987; Jahn 1990; Liu et al. 1992; Huang et al. 2004).

NE China can be divided into two main tectonic domains: the south Precambrian Sino-Korean Craton and the north Paleozoic Xing'an-Mongolian fold belt (Chen et al. 2003). Menzies and Xu (1998) suggested that the Archean lithostratigraphy beneath Sino-Korean Craton had survived which was characterized by a cold, thick, refractory mantle keel in early Palaeozoic based on geochronological and geochemical evidences of kimberliteborn xenoliths and diamonds from Shandong and Liaoning provinces. On the basis of seismic tomography, Liu et al. (1992) pointed out that the lithosphere in the eastern part of the NCC is $<80 \mathrm{~km}$ thick and even thinner around the Bo Sea. Zhang (2005) based on olivine xenocrysts with clear compositional zonations in early Cretaceous Fangcheng basalts erupted in Luxi region of Shandong province, north China concluded that mantlemelt reaction was significant in the Mesozoic lithospheric mantle beneath the southeastern portion of the Sino-Korean Craton which he considered to be responsible for the replacement of lithospheric mantle from the Paleozoic refractory peridotitic mantle to the late Mesozoic fertile and enriched mantle. During the Mesozoic and Cenozoic, the tectonic evolution of China was closely related to the complex interaction of the Eurasian, Indian and Pacific plates. The collision between the NCC and adjacent areas may have been associated with the reactivation of the Tancheng-Lujiang (Tan-Lu) fault extending about $2000 \mathrm{~km}$. The Tan-Lu system is regarded as a major transcurrent intracontinental fault zone with over $700 \mathrm{~km}$ of sinistral displacement and it may have taken place in Cretaceous time (Xu et al. 1987; Xu 1993; Xu and Zhu 1994).

Cenozoic basalts are widely distributed along the eastern China from north of Heilongjiang province to south of Hainan island, and South China Sea (Zou et al. 2000). The Cenozoic volcanic rocks from Anhui-Jiangsu provinces are spread over an area of more than $2000 \mathrm{~km}^{2}$ in eastern Anhui and western Jiangsu. The spatial distribution of volcanic rocks in this region is controlled by the NNE-trending Tan-Lu fault and its adjacent NW-trending basins and faults which can be divided into three periods (Chen and Peng 1985; Dostal et al. 1991): (A) volcanic rocks of 1st period - non-marine fissure eruption of Paleogene located in the central and eastern parts of the Subei basin are mainly tholeiites, olivine tholeiites and alkali basalts intercalated with Paleocene, Eocene and Oligocene sedimentary sequences. (B) volcanic rocks of $2 \mathrm{nd}$ period - mainly lava flows and pyroclastic rocks of Pliocene lie on the top of fossiliferous sediments of Miocene and early Pliocene age. The Pliocene volcanic rocks located in the southwestern part of the Subei basin include alkali olivine basalts and related rocks, covering an area of about $1500 \mathrm{~km}^{2}$. (C) volcanic rocks of 3 rd period - the eruption process of this period occurred in Pleistocene and produced basanites and olivine nephelinites with abundant peridotite xenoliths and megacrysts.

The xenoliths of this study generally range from 10 to $20 \mathrm{~cm}$ in diameter and are green in their appearance which contain pale green

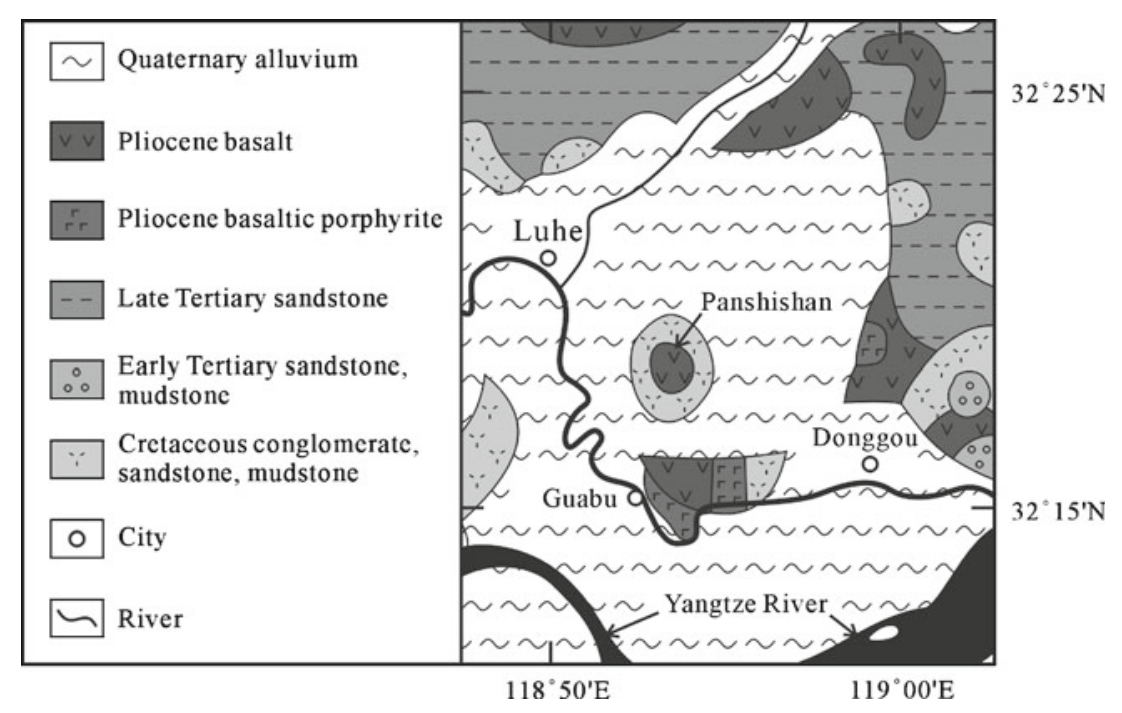

Figure 2. Geological map showing the sampling location of Panshishan in the Jiangsu province, eastern China. 


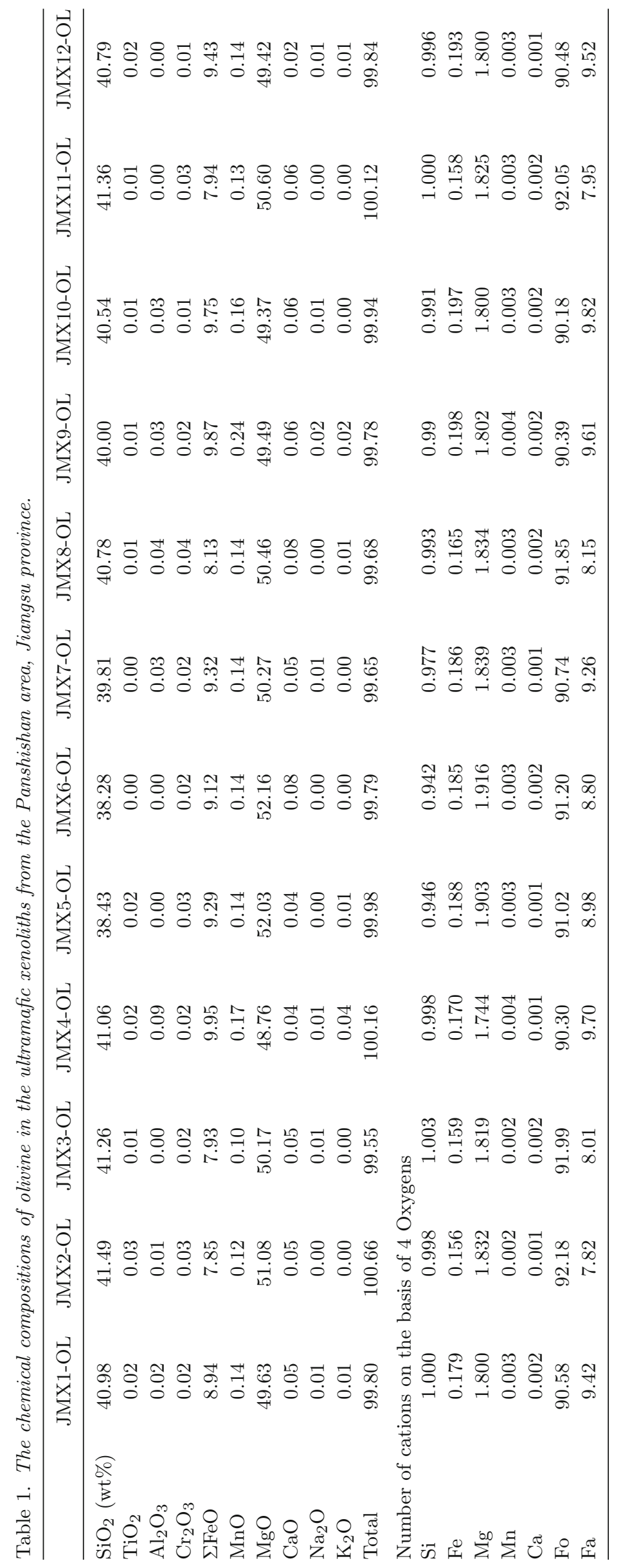



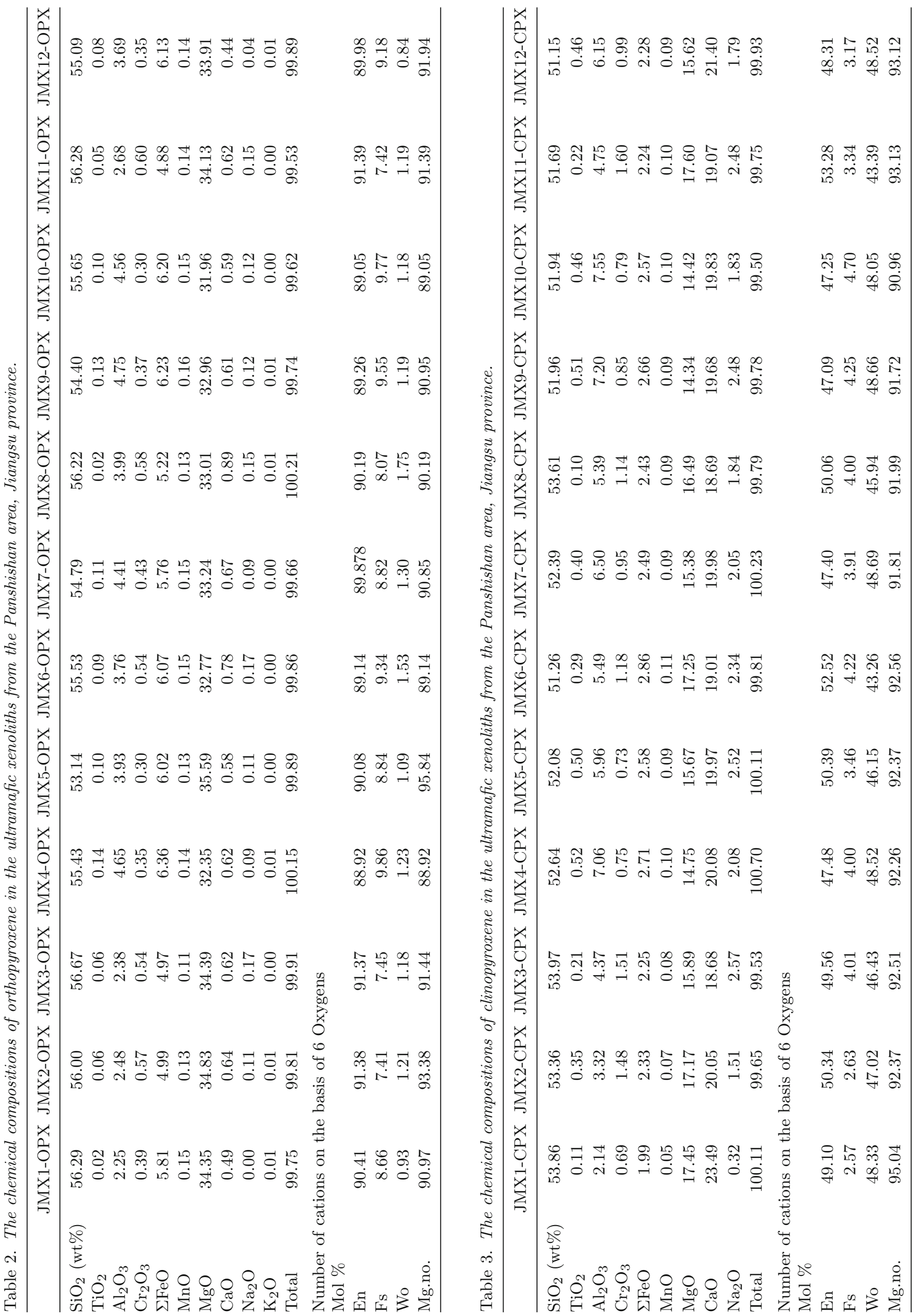


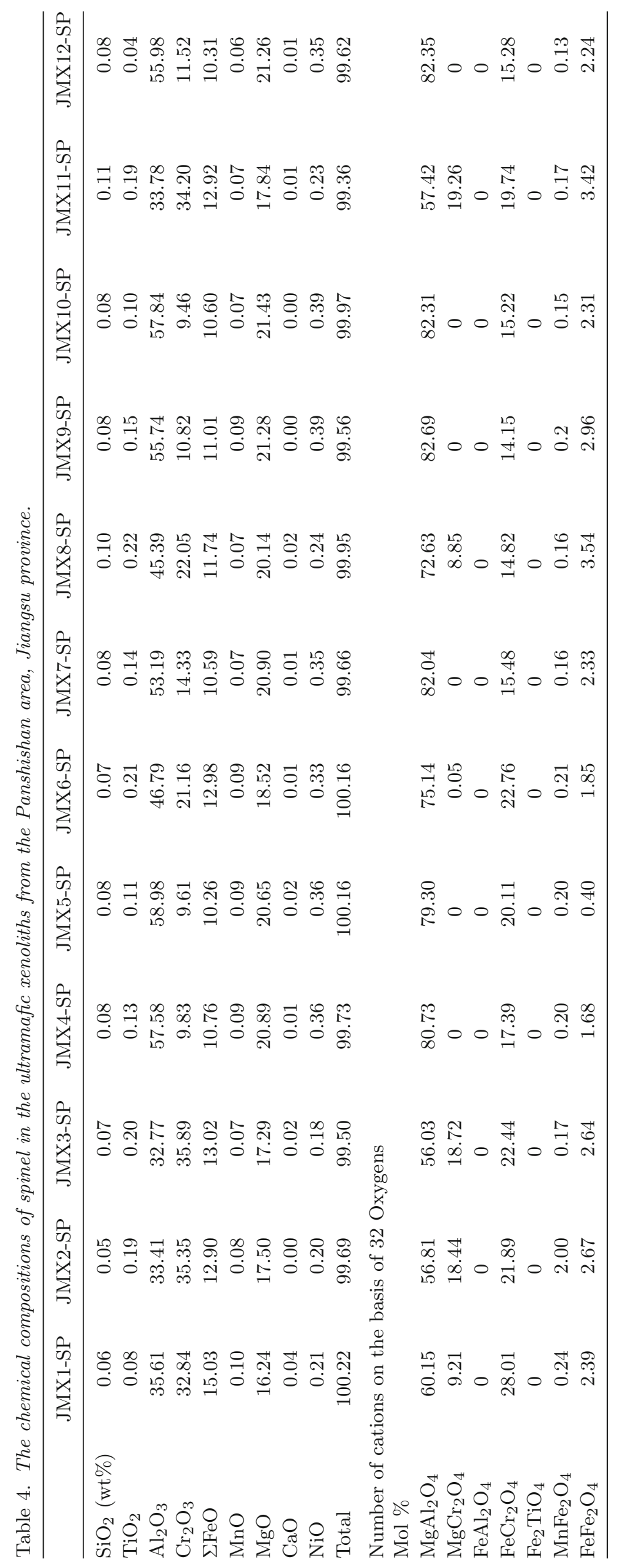


olivine, brownish orthopyroxene, bright emerald green clinopyroxene and black low spinel. They have fine- to coarse-grained porphyroclastic texture with curved cleavage.

\section{Analytical methods}

Twelve Jiangsu ultramafic xenoliths were selected for mineral and bulk chemical analyses. The major element compositions of four constituent phases were analyzed by a 4-spectrometer ARL-SEMQ electron microprobe at the Central Geological Survey Taipei, and corrected with the Bence and Albee correction procedures (Bence and Albee 1968). The electron beam current and accelerating voltage were usually $15 \mathrm{nA}$ and $15 \mathrm{kV}$ respectively, with a counting time of 20 s. Synthetic and natural minerals were utilized as standards. Analytical results of each mineral represent more than five complete point analyses of each grain, and several grains from different parts of each sample. The bulk chemical analyses of the ultramafic xenoliths in the present study have been carried out by colorimetry ( $\mathrm{Si}, \mathrm{Al}, \mathrm{Ti}, \mathrm{P}$ ), atomic absorption ( $\mathrm{Fe}, \mathrm{Mg}, \mathrm{Ca}$, $\mathrm{Na}, \mathrm{K}, \mathrm{Mn}, \mathrm{Cr}, \mathrm{Ni}$ ) and inductively coupled plasma mass spectrometry ( $\mathrm{Ba}, \mathrm{Co}, \mathrm{Cu}, \mathrm{Hf}, \mathrm{Li}, \mathrm{Nb}, \mathrm{Pb}$, Rb, Sc, Sr, Th, U, V, Y, Zn, Zr and REEs) at the National Taiwan and Tsing-Hua Universities.

The calibration curves were constructed using USGS standard rocks BHVO-1, AGV-1, BCR-1, $\mathrm{W}-2, \mathrm{G} 2$ and NBS standard rock basalt. The precision of the analyses in the present study is estimated to be around $\pm 2 \%$ for colorimetric and atomic absorption methods and better than $\pm 5 \%$ for all ICP-MS analyses.

Seven ultramafic xenoliths (JMX1, JMX2, JMX3, JMX6, JMX7, JMX10, and JMX11) were selected for $\mathrm{Sr}$ and $\mathrm{Nd}$ isotopic composition analyses. Isotopic compositions of the $\mathrm{Sr}$ and $\mathrm{Nd}$ were measured using a Finnigan MAT 262 mass spectrometer at National Cheng Kung University followed the procedures of Smith and Huang (1997). Precision of $\mathrm{Nd}$ and $\mathrm{Sr}$ isotopic compositions is better than $\pm 0.000010(2 \sigma)$.

\section{Mineral composition of ultramafic xenoliths}

The ultramafic xenoliths found in Cenozoic basaltic rocks from the Panshishan area of Jiangsu province are mainly spinel-lherzolites. The ultramafic xenoliths found in the study area are mainly spinel-lherzolites. Most of them consist of olivine, clinopyroxene, orthopyroxene and spinel. The clinopyroxenes in the ultramafic xenoliths are generally interstitial and smaller in size than coexisting olivine and orthopyroxene. Spinels form a common accessory phase $(2-5$ vol. $\%)$ in ultramafic xenoliths. Under microscopic observation, the spinel-lherzolites have porphyroclastic texture with curved cleavage and wavy extinction.

The results of the mineral chemistry of ultramafic xenoliths from the Panshishan area of Jiangsu province are listed in tables 1-4.

Based on classification norms proposed by Menzies (1983), the ultramafic xenoliths in the present study belong to type-I xenoliths. The Fovalues in olivine of the ultramafic xenoliths range from 90.18 to 92.18 which indicate that they may be residues formed by successive partial melting of the primary mantle. In the xenoliths, orthopyroxene shows a restricted range in $\mathrm{Mg}: \mathrm{Fe}: \mathrm{Ca}$ ratios varying from $\mathrm{En}_{89} \mathrm{Fs}_{10} \mathrm{Wo}_{1}$, clinopyroxene ranges from $\mathrm{Wo}_{43} \mathrm{En}_{53} \mathrm{Fs}_{4}$ to $\mathrm{Wo}_{49} \mathrm{En}_{47} \mathrm{Fs}_{4}$. According to the classification of Stephens and Dawson (1977), these pyroxenes fall within the field of enstatite and diopside/chrome-diopside. Diopsides are comparably magnesium rich with high $\mathrm{Mg} /(\mathrm{Mg}+\mathrm{Fe})=$ 90.96-95.04. They are relatively rich in $\mathrm{Al}_{2} \mathrm{O}_{3}$ (2.14-7.55\%), $\mathrm{Na}_{2} \mathrm{O}(0.32-2.57 \%), \mathrm{TiO}_{2}(0.10-$ $0.52 \%)$ and $\mathrm{Cr}_{2} \mathrm{O}_{3}(0.69-1.60 \%)$ but poor in $\Sigma \mathrm{FeO}$ (1.99-2.86\%). Enstatites have $\Sigma \mathrm{FeO}$ contents ranging from 4.88 to $6.36 \%$. The presence of low-Al $(2.25-4.65 \%)$ and high- $\mathrm{Mg} \#(88.92-95.84)$ is a typical characteristic of depleted xenoliths ( $\mathrm{Su}$ et al. 2009). The plots of $\mathrm{Cr}_{2} \mathrm{O}_{3}$ vs. $\mathrm{TiO}_{2}$ for clinopyroxene of ultramafic xenoliths (figure 3 ) fall within

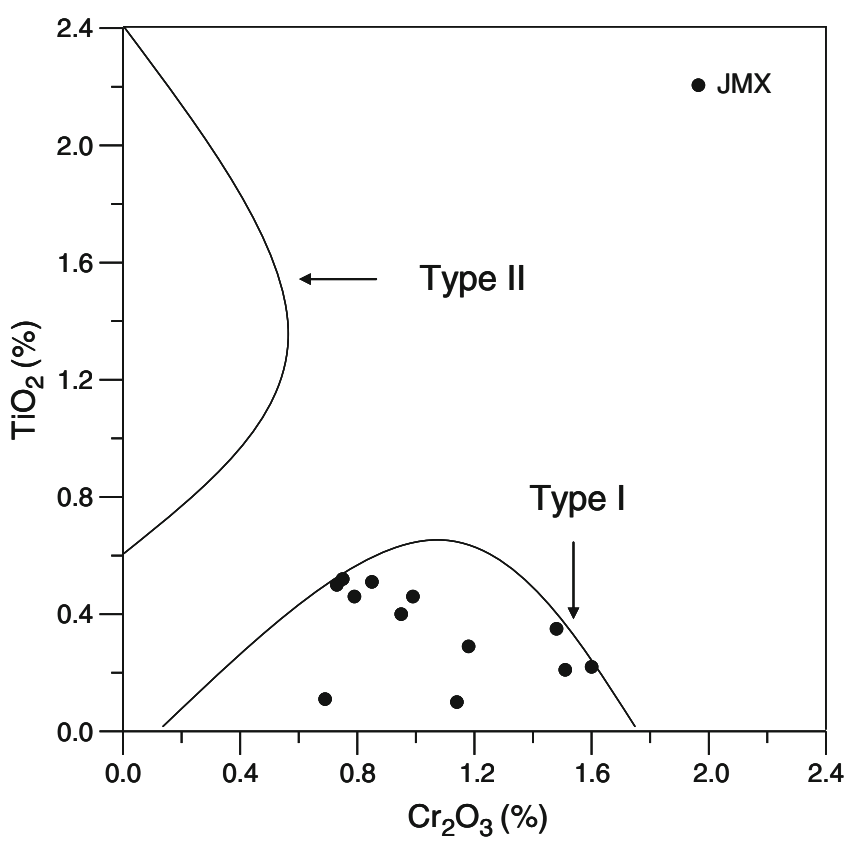

Figure 3. $\mathrm{TiO}_{2}$ vs. $\mathrm{Cr}_{2} \mathrm{O}_{3}$ plots for clinopyroxene of ultramafic xenoliths from the Jiangsu province. Fields for Type I and Type II from Kempton (1987). 


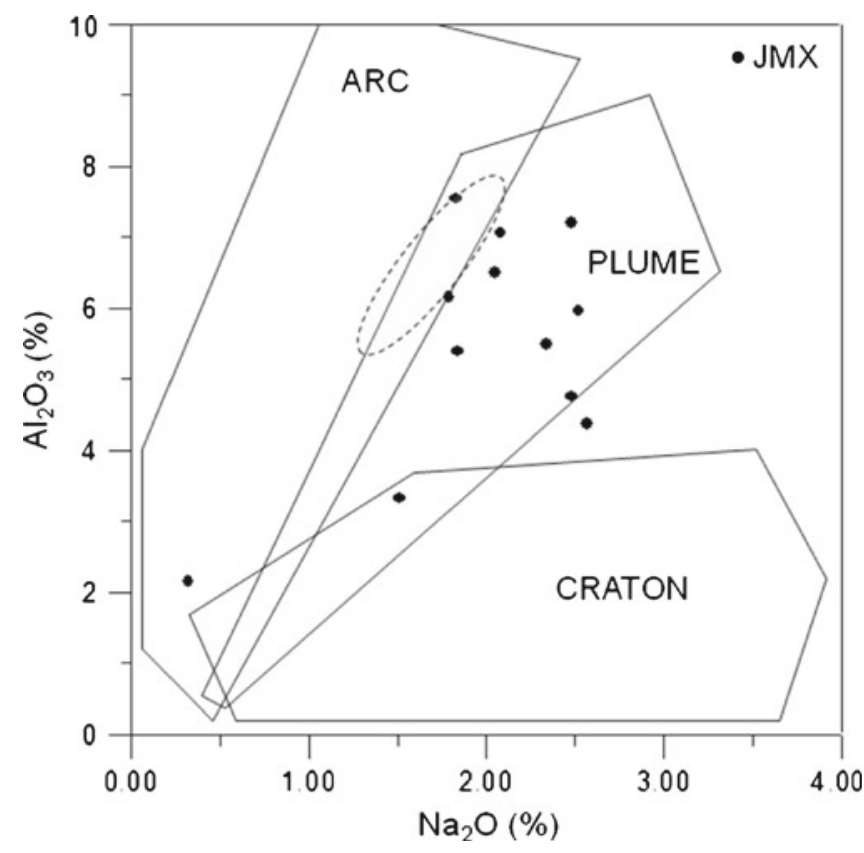

Figure 4. $\mathrm{Al}_{2} \mathrm{O}_{3}$ vs. $\mathrm{Na}_{2} \mathrm{O}$ plots for clinopyroxene of ultramafic xenoliths from the Jiangsu province. Fields for ARC, PUUME and CRATON from Kepezhinskas et al. (1995). Closed ellipse shows the distribution range of clinopyroxene from southern China (Ho 1998).

type-I xenoliths (Kempton 1987). The Mg\# and $\mathrm{Cr} \#$ in all clinopyroxenes for ultramafic xenoliths from the Panshishan area range from 90.96 to 95.04 and 11.92 to 36.56 which fall within the refractory mantle field (Zheng et al. 2003), defined by the $\mathrm{Cr} \#(\geq 10)$ and $\mathrm{Mg} \#(\geq 91)$. The plots of $\mathrm{Al}_{2} \mathrm{O}_{3}$ vs. $\mathrm{Na}_{2} \mathrm{O}$ for clinopyroxene of ultramafic xenoliths (figure 4) fall within the field of plume defined by Kepezhinskas et al. (1995).

The spinels have characteristically moderate to high $\mathrm{Cr}_{2} \mathrm{O}_{3}$ contents $(9.46 \sim 35.89 \%)$ and low $\mathrm{Al}_{2} \mathrm{O}_{3}(32.77 \sim 58.98 \%)$ and fall with the range of $\mathrm{Cr}$-spinel and $\mathrm{Al}$-spinel. The $\mathrm{Cr} /(\mathrm{Cr}+\mathrm{Al})$ ratios of spinel of sample JMX1, JMX2, JMX3 and JMX11 are higher than 50.

\section{Bulk chemistry of ultramafic xenoliths}

The results of the bulk chemistry of ultramafic xenoliths from the Panshishan area of Jiangsu province are listed in tables 5 and 6 . The $\mathrm{SiO}_{2}$, $\mathrm{MgO}$ and $\Sigma \mathrm{FeO}$ contents of the ultramafic xenoliths ranging from $41.12 \%-44.68 \%, 38.09 \%-43.39 \%$ and $7.59 \%-9.09 \%$, respectively. The contents of major elements of ultramafic xenoliths display limited variations. The ultramafic xenoliths have higher $\mathrm{MgO}$ content, but lower $\mathrm{Al}_{2} \mathrm{O}_{3}, \mathrm{TiO}_{2}, \mathrm{CaO}$ and $\mathrm{Na}_{2} \mathrm{O}$ contents than those of primitive mantle proposed by Sun and McDonough (1989).

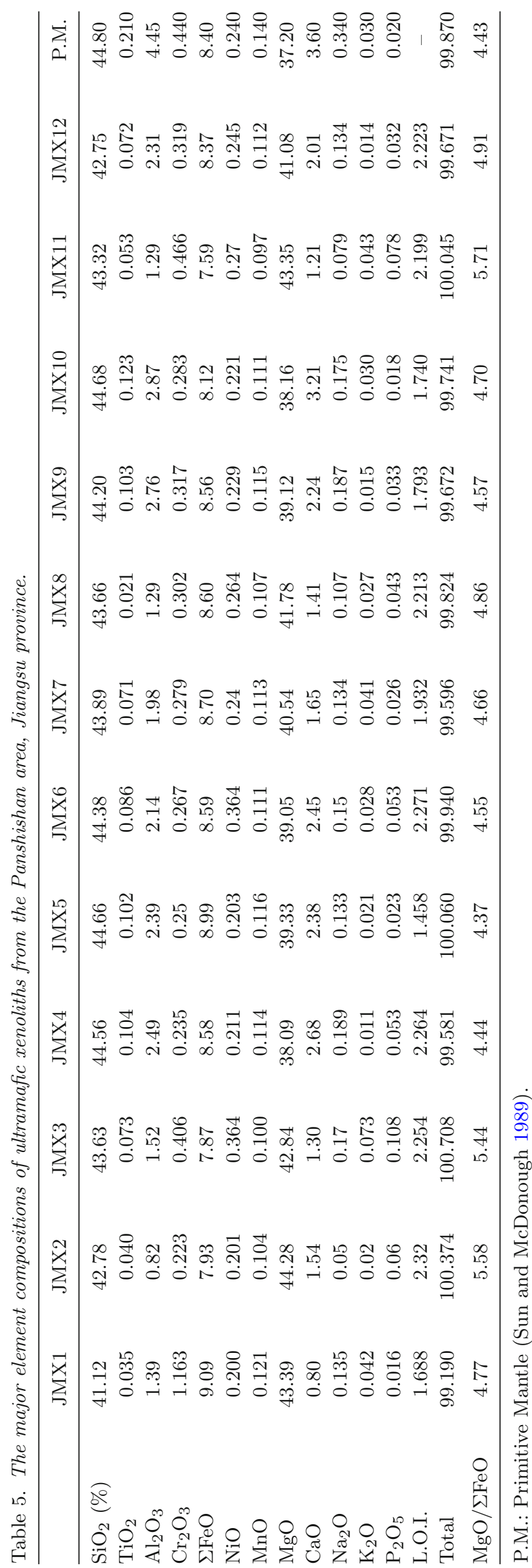




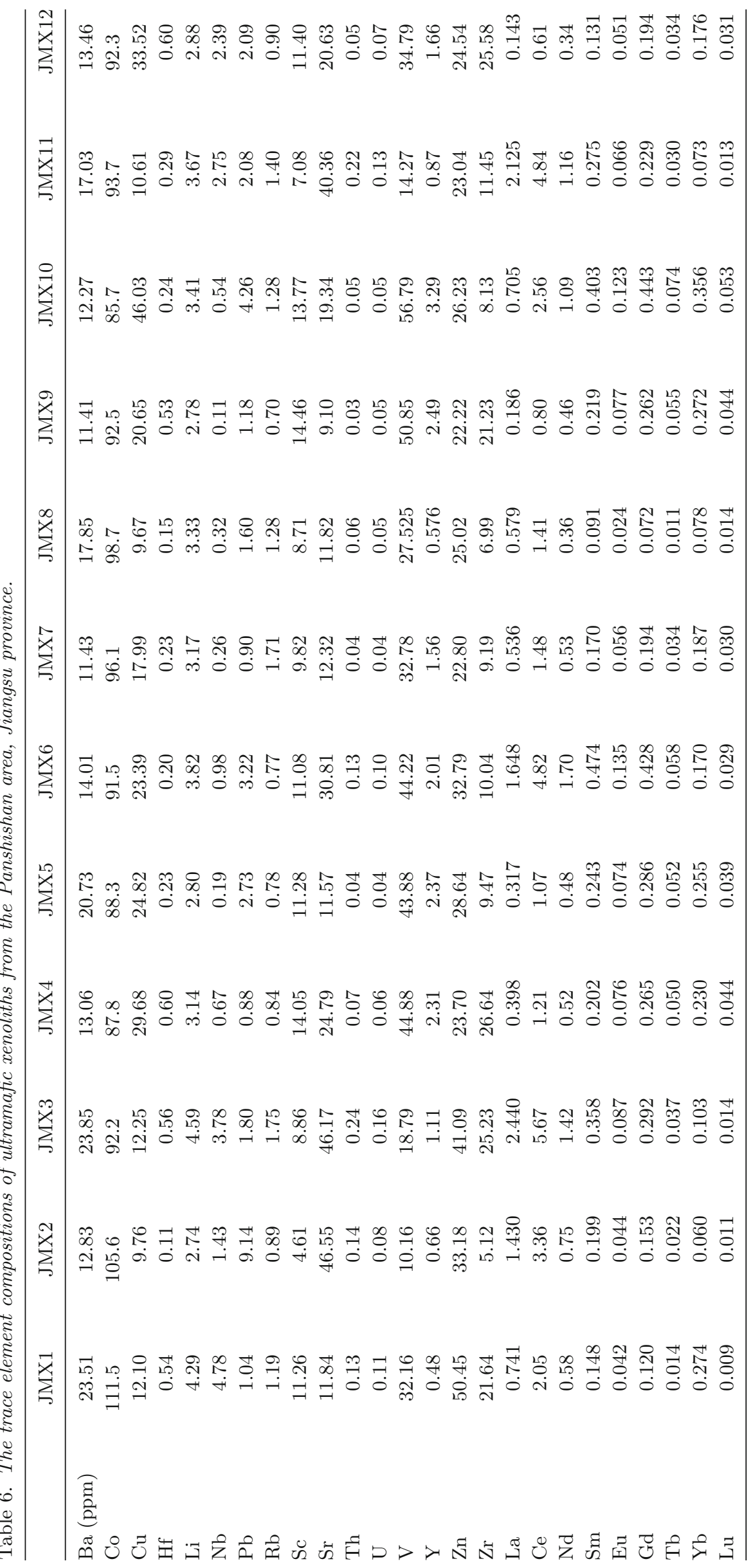



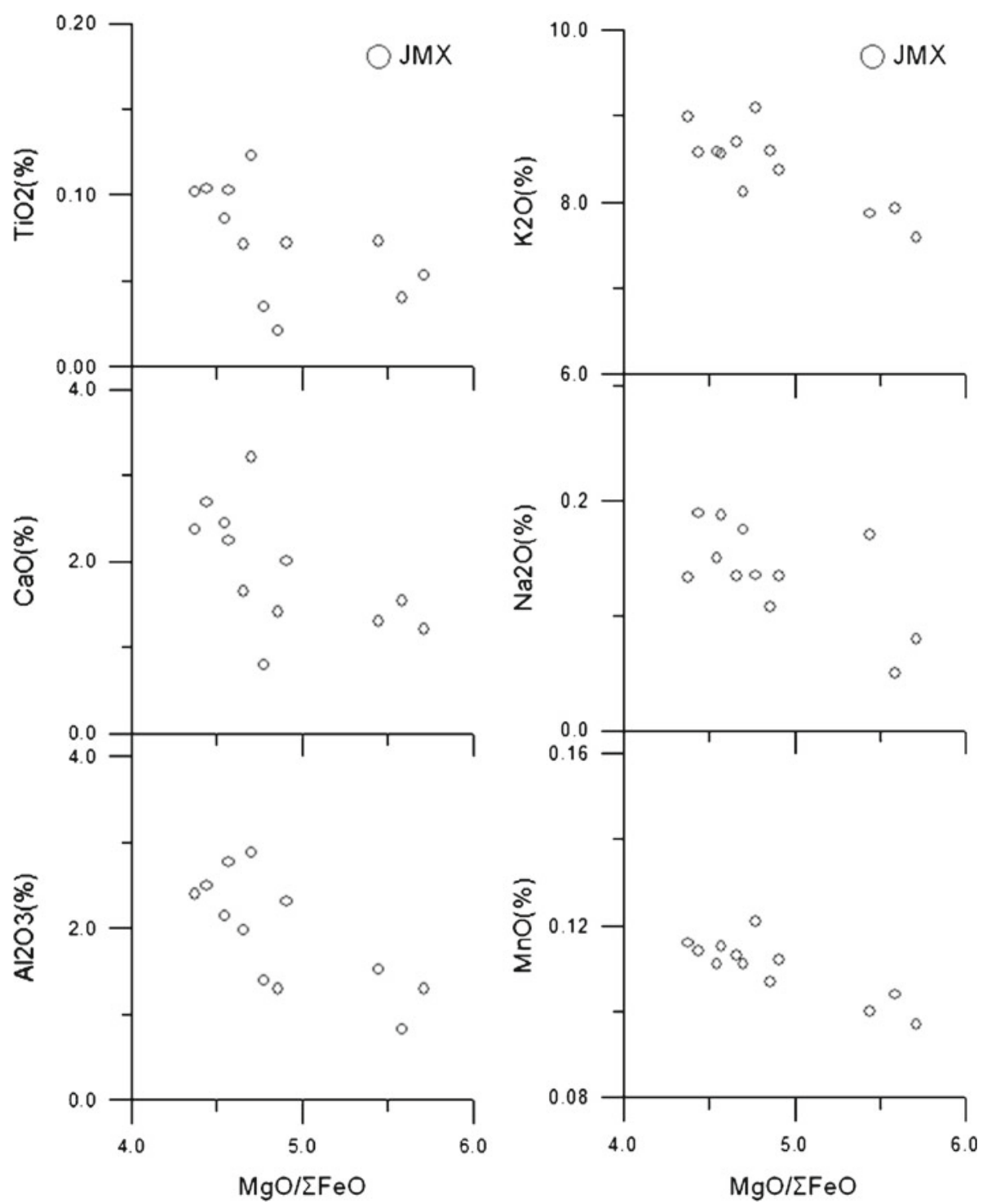

Figure 5. Major elements vs. $\mathrm{MgO} / \Sigma \mathrm{FeO}$ ratio plots for ultramafic xenoliths from Jiangsu province.

In the Panshishan ultramafic xenoliths, $\mathrm{Al}_{2} \mathrm{O}_{3}$, $\mathrm{TiO}_{2}, \mathrm{CaO}, \mathrm{K}_{2} \mathrm{O}, \mathrm{Na}_{2} \mathrm{O}$ and $\mathrm{MnO}$ tend to decrease with increasing $\mathrm{MgO} / \Sigma \mathrm{FeO}$ ratios (figure 5). The chemical variation may be related to the partial melting of the mantle source which removed the elements mentioned above.

The abundance of $\mathrm{Sr}, \mathrm{Th}, \mathrm{Rb}, \mathrm{U}$ and $\mathrm{Nb}$ are positively correlated with $\mathrm{MgO} / \Sigma \mathrm{FeO}$ ratios of the ultramafic xenoliths (figure 6). Except for samples JMX5, JMX9 and JMX12, the chondritenormalized rare earth element (REE) patterns of the ultramafic xenoliths from the Panshishan area (figure 7) show moderate sloping with light rare earth element (LREE) enrichment. The samples JMX2, JMX3 and JMX11 are decuple higher in light rare elements when compared with chondrete. The $(\mathrm{La} / \mathrm{Yb})_{\mathrm{N}}$ ratios of the samples JMX5, JMX9 and JMX12 are $0.89,0.49,0.58$, respectively. It should be noted that the spinel-therzolite xenoliths can be divided into two types in the Panshishan area: (1) an E-type enriched in LREE with $(\mathrm{La} / \mathrm{Yb})_{\mathrm{N}}$ ratios varying from 1.24 to 20.90 ; (2) a D-type depleted in LREE with $(\mathrm{La} / \mathrm{Yb})_{\mathrm{N}}$ ratios varying from 0.49 to 0.89 (such as samples JMX5, JMX9 and JMX12). The isotopic ratios of the ultramafic xenoliths in the Panshishan area are ${ }^{87} \mathrm{Sr} /{ }^{86} \mathrm{Sr}=0.702907-0.704349$ and ${ }^{143} \mathrm{Nd} /{ }^{144} \mathrm{Nd}=$ 0.512683-0.513371 (table 7, figure 8). In the primitive mantle normalized incompatible element pattern (figure 9), the ultramafic xenoliths found in Jiangsu province are enriched in $\mathrm{Rb}, \mathrm{Ba}, \mathrm{U}, \mathrm{Nb}, \mathrm{K}$, $\mathrm{La}, \mathrm{Ce}, \mathrm{Sr}, \mathrm{P}$ and $\mathrm{Zr}$ contents which may be related to the $\mathrm{CO}_{2}-\mathrm{H}_{2} \mathrm{O}$-fluids metasomatism. The Th, Ti and $\mathrm{Nd}$ depletions in the Panshishan ultramafic xenoliths may be related to the partial melting of the mantle source. 


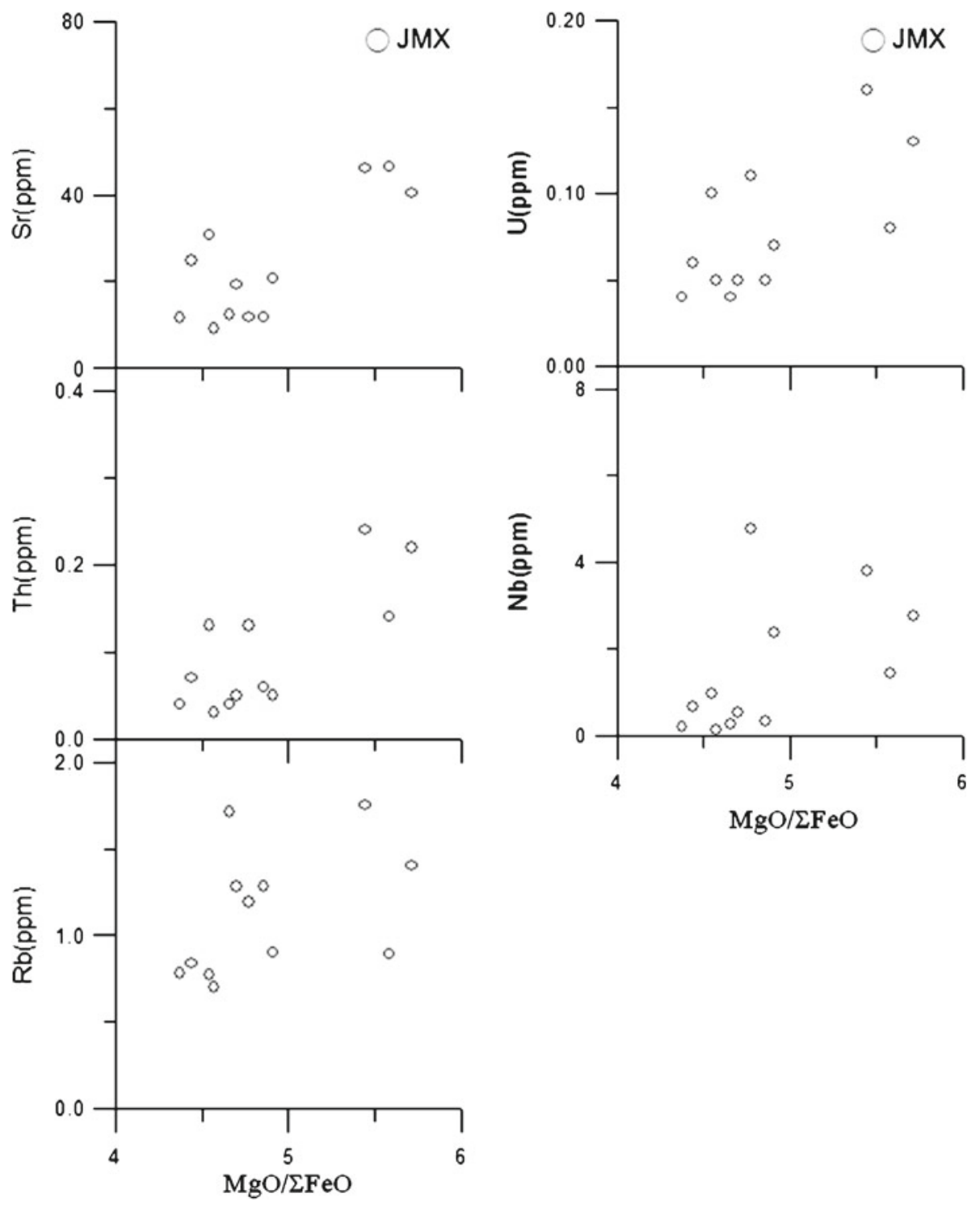

Figure 6. $\mathrm{Sr}, \mathrm{Th}, \mathrm{Rb}, \mathrm{U}$, and $\mathrm{Nb}$ vs. $\mathrm{MgO} / \Sigma \mathrm{FeO}$ ratio plots for ultramafic xenoliths from Jiangsu province.

\section{Discussion}

\subsection{Geochemical characteristics and genesis of the ultramafic xenoliths in the Panshishan area and their geological implication}

The Panshishan ultramafic xenoliths belong to type I xenoliths and have high Fo-values in olivine which indicate that the ultramafic xenoliths may represent the residues of partial melting. The $\mathrm{Mg} \#$ and $\mathrm{Cr} \#$ in all clinopyroxenes for ultramafic xenoliths from the Panshishan area suggested that an old refractory mantle beneath the Panshishan region. The plots of $\mathrm{Al}_{2} \mathrm{O}_{3}$ vs. $\mathrm{Na}_{2} \mathrm{O}$ for clinopyroxene of ultramafic xenoliths (figure 4) suggested that the mantle source beneath the study area may be similar to clinopyroxene of mantle source related to subduction (Condie et al. 2004). Xia et al. (2013) pointed out the ENCC experienced widespread lithospheric thinning from a thick $(\sim 200 \mathrm{~km})$, cold $\left(\sim 40 \mathrm{~mW} / \mathrm{m}^{2}\right)$ and highly refractory lithospheric mantle in the mid-Ordovician to a hot (60-80 $\left.\mathrm{mW} / \mathrm{m}^{2}\right)$, thin $(60-80 \mathrm{~km})$ and fertile lithospheric mantle since the late Mesozoic.

The major element contents vs. $\mathrm{MgO} / \mathrm{\Sigma FeO}$ ratios of the ultramafic xenoliths indicate that they may represent residues formed by different degrees of partial melting from the upper mantle. The positive correlation between some trace element contents and $\mathrm{MgO} / \Sigma \mathrm{FeO}$ ratios (figure 6) provides support for the suggestion that mantle metasomatism occurred in the Panshishan area. According to mantle xenoliths (Tatsumoto et al. 1992; Fan et al. 2000; Chen et al. 2001; Xu 2002; Zhou et al. 2002; Xu and Bodinier 2004), the Cenozoic lithospheric mantle beneath the NCC is fertile in major oxides and depleted in $\mathrm{Sr}-\mathrm{Nd}-\mathrm{Pb}$ isotopic ratios relative to primitive mantle. The temporal and 
spatial variations of $\mathrm{Sr}-\mathrm{Nd}-\mathrm{Pb}$ isotopic compositions of middle Jurassic to late Cretaceous mafic rocks across the Chenzhou-Linwu Fault within the South China Block proposed by Wang et al. (2008), suggest that the multiple mantle reservoirs including FOZO-, DMM-, EM1- and EM2like components exist beneath the South China Block.

The varied $(\mathrm{La} / \mathrm{Yb})_{\mathrm{N}}$ ratios in the Panshishan xenoliths may be interpreted as due to mantle

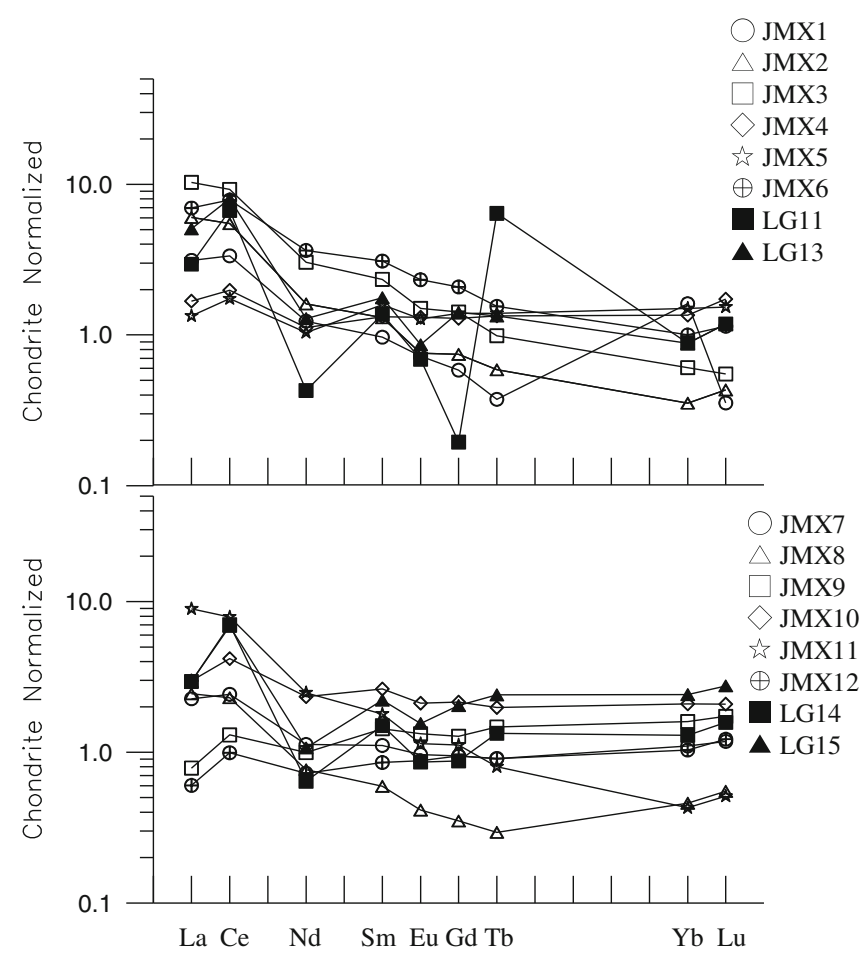

Figure 7. Chondrite-normalized REE patterns of ultramafic xenoliths from Jiangsu province. heterogeneity beneath the Panshishan region. The $\mathrm{Sr}-\mathrm{Nd}$ variation in the Panshishan xenoliths may be related to the heterogeneous characteristics in the Panshishan region and the influence of different degrees of fluids-metasomatism on mantle composition. The enrichment of $\mathrm{Rb}, \mathrm{Ba}, \mathrm{U}, \mathrm{Nb}, \mathrm{K}$, $\mathrm{La}, \mathrm{Ce}, \mathrm{Sr}, \mathrm{P}$ and $\mathrm{Zr}$ contents in the Panshishan xenoliths may be caused by the $\mathrm{CO}_{2}-\mathrm{H}_{2} \mathrm{O}$-fluids metasomatism. Our results are consistent with previous studies (e.g., Griffin et al. 1992, 1998; Yuan 1996; Fan et al. 2000; Xu et al. 2000) which revealed that Cenozoic lithospheric mantle of North China Block was characterized by chemically fertile but $\mathrm{Sr}-\mathrm{Nd}$ isotopically depleted compositions.

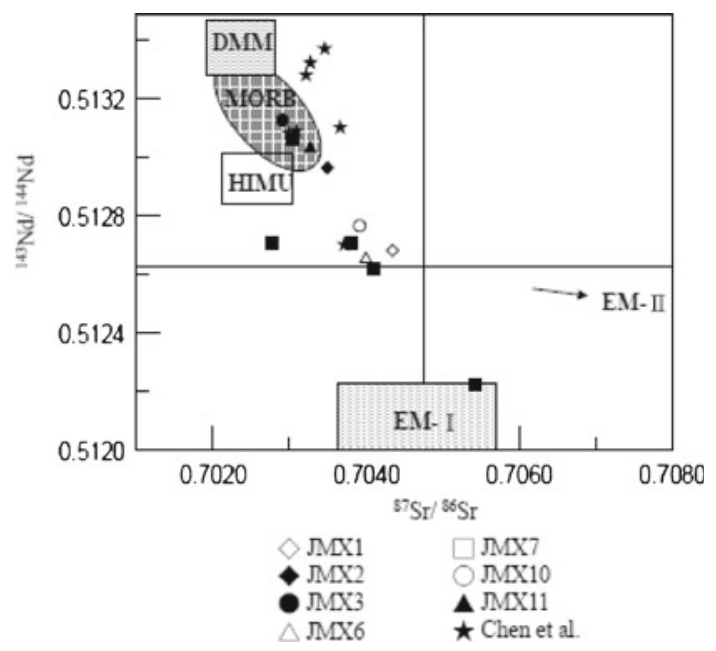

Figure 8. ${ }^{87} \mathrm{Sr} /{ }^{86} \mathrm{Sr}$ vs. ${ }^{143} \mathrm{Nd} /{ }^{144} \mathrm{Nd}$ plots for ultramafic xenoliths from Jiangsu province (star from Chen et al. 1990; closed squares from Dai et al. 2008).

Table 7. The Sr-Nd isotopic data of ultramafic xenoliths from the Panshishan area, Jiangsu province.

\begin{tabular}{lccc}
\hline Sample no. & Rock type & ${ }^{87} \mathrm{Sr} /{ }^{86} \mathrm{Sr}$ & $143 \mathrm{Nd} /{ }^{144} \mathrm{Nd}$ \\
\hline $\mathrm{JMX}^{\mathrm{a}}$ & Spinel-lherzolite & 0.703491 & 0.512965 \\
$\mathrm{JMX}^{\mathrm{a}}$ & Spinel-lherzolite & 0.704349 & 0.512683 \\
$\mathrm{JMX}^{\mathrm{a}}$ & Spinel-lherzolite & 0.703916 & 0.512766 \\
$\mathrm{JMX}^{\mathrm{a}}$ & Spinel-lherzolite & 0.703272 & 0.513035 \\
$\mathrm{JMX}^{\mathrm{a}}$ & Spinel-lherzolite & 0.703050 & 0.513061 \\
$\mathrm{JMX}^{\mathrm{a}}$ & Spinel-lherzolite & 0.702907 & 0.513127 \\
$\mathrm{JMX}^{\mathrm{a}}$ & Spinel-lherzolite & 0.703999 & 0.512659 \\
$\mathrm{PS}^{\mathrm{b}}$ & Spinel-lherzolite & 0.703273 & 0.513324 \\
$\mathrm{PSS}^{\mathrm{b}}$ & Spinel-lherzolite & 0.702996 & 0.513083 \\
$\mathrm{PSS2}^{\mathrm{b}}$ & Spinel-lherzolite & 0.703089 & 0.513090 \\
$\mathrm{PSS3}^{\mathrm{b}}$ & Spinel-lherzolite & 0.703457 & 0.513371 \\
$\mathrm{PSS6}^{\mathrm{b}}$ & Spinel-lherzolite & 0.703659 & 0.513102 \\
$\mathrm{PSS}^{\mathrm{b}}$ & Spinel-lherzolite & 0.703218 & 0.513282 \\
LHFS $^{\mathrm{b}}$ & Spinel-lherzolite & 0.703716 & 0.512703 \\
\hline
\end{tabular}

Note: ${ }^{\mathrm{a}}$ Present study. ${ }^{\mathrm{b}}$ Chen et al. (1990). 


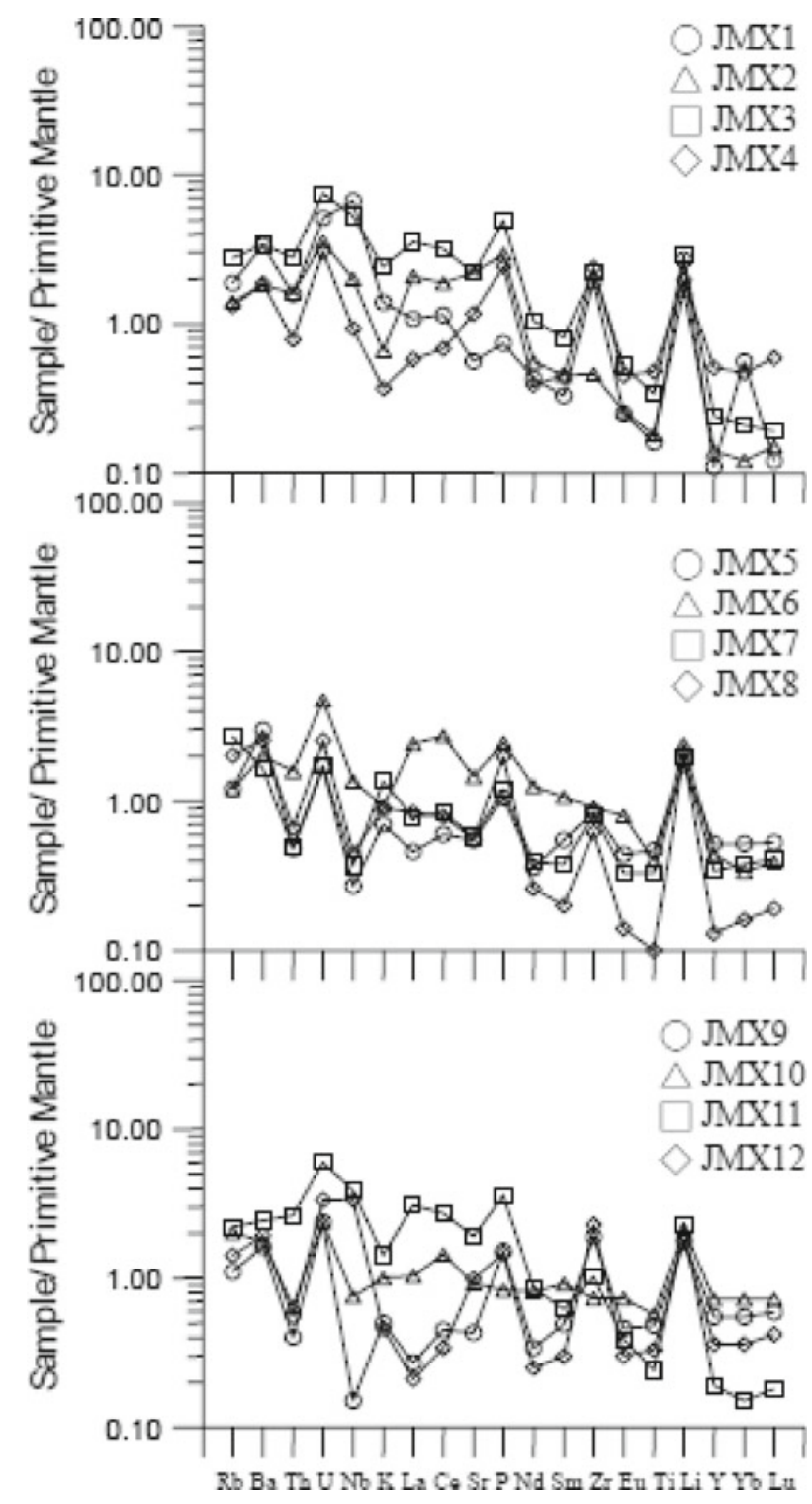

Figure 9. Primitive mantle normalized incompatible element patterns for ultramafic xenoliths from Jiangsu province.

\subsection{Upper mantle $P-T$ conditions and mantle metasomatism beneath North China Craton (NCC)}

Most xenoliths are useful tools to estimate the pressures and temperatures of formation in terms of available experimental data. These temperature and pressure estimates from ultramafic xenoliths may provide important information on the thermal and dynamic evolution of their lithospheric source regions.

There are many geothermobarometers based on the mineral assemblages of ultramafic rocks, and each geothermometer or geobarometer has its own particular criteria for appropriate use. After reevaluating the geothermobarometers commonly used in the studies of basalt-borne xenoliths, $\mathrm{Xu}$ et al.
Table 8. The equilibrium conditions of utramafic xenoliths from the Panshishan area, Jiangsu province.

\begin{tabular}{lccc}
\hline & $\begin{array}{c}\text { Fabries (1979) } \\
\text { Spinel-olivine }\left({ }^{\circ} \mathrm{C}\right)\end{array}$ & $\begin{array}{c}\text { Mysen }(1976) \\
\text { Opx-Cpx }\left({ }^{\circ} \mathrm{C}\right)\end{array}$ & $\begin{array}{c}\text { Mysen }(1976) \\
\text { Opx-Cpx }(\mathrm{kb})\end{array}$ \\
\hline JMX-1 & 913 & 920 & 13 \\
JMX-2 & 962 & 916 & 13 \\
JMX-3 & 975 & 1009 & 19 \\
JMX-4 & 946 & 1045 & 22 \\
JMX-5 & 893 & 982 & 17 \\
JMX-6 & 976 & 1016 & 20 \\
JMX-7 & 992 & 1017 & 20 \\
JMX-8 & 930 & 1028 & 21 \\
JMX-9 & 948 & 1009 & 19 \\
JMX-10 & 984 & 990 & 18 \\
JMX-11 & 967 & 1017 & 20 \\
JMX-12 & 981 & 966 & 16 \\
\hline
\end{tabular}

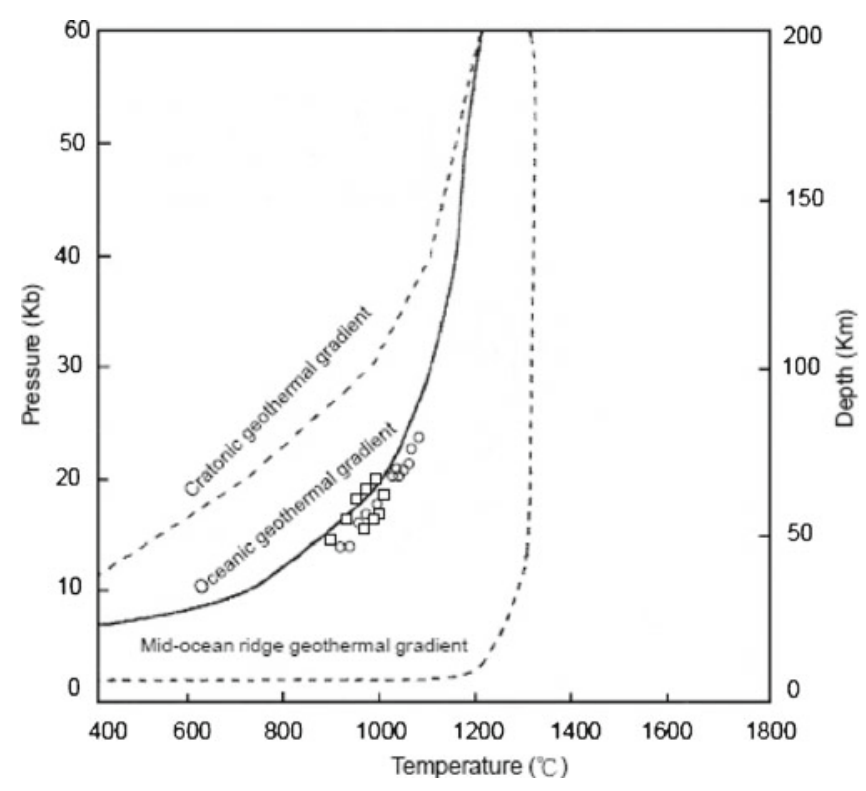

Figure 10. The $\mathrm{P}-\mathrm{T}$ conditions of the upper mantle beneath the study area (modified after Wyllie 1981; the open circles, this study; open squares from Chen et al. 2001).

(1998) recommended a protocol for pressure and temperature calculation in ultramafic xenoliths. The pressures and temperatures of the lherzolite xenoliths from Jiangsu province were calculated following these protocols. Calculations based on clinopyroxene geothermometry (Mysen 1976) and olivine-spinel geothermometry (Fabries 1979) reveal that the equilibrium conditions of the spinel lherzolite xenoliths in the Panshishan area are: $\mathrm{T}=913 \sim 1045^{\circ} \mathrm{C}, \mathrm{P}=13 \sim 22 \mathrm{~kb}$ corresponding to depths of $45 \sim 83 \mathrm{~km}$ (table 8 , figure 10). We incorporate the $\mathrm{P}-\mathrm{T}$ data from Hannuoba xenoliths, Sino-Korean Craton in figure 10 which suggest that the geothermal gradient of the upper mantle beneath the study area and Hannuoba 
area is approximately similar to oceanic geotherm. Tang et al. (2006) proposed that continental collision (India-Eurasia collision) and asthenospheric upwelling might be important mechanisms for triggering the melting of asthenospheric material with/without minor component of old lithospheric mantle. Xia et al. (2013) suggested that the present NCC lithospheric mantle may be interpreted in terms of relic mantle after the thinning event, while some newly accreted and cooled asthenospheric mantle do exist. The relatively thin crust and lithosphere in eastern China may be caused by mantle upwelling which triggered partial melting of lithospheric mantle (Chung 1999; Deng et al. 2004; Lee et al. 2006). The geothermal gradient of the upper mantle beneath the study area is suggested that lithospheric mantle thinning accompanied by asthenosphere upwelling has occurred and a newly accreted and cooled asthenospheric mantle may exist beneath the study area. Based on Re-Os studies (Gao et al. 2002; Zhi and Qin 2004), ancient lithosphere beneath the Central Zone of the NCC has been documented in mantle xenoliths which do not have low ${ }^{143} \mathrm{Nd} /{ }^{144} \mathrm{Nd}$ and high ${ }^{87} \mathrm{Sr} /{ }^{86} \mathrm{Sr}$ ratios (Song and Fery 1989; Rudnick et al. 2004; Xu et al. 2004).

According to the equilibrium condition for the enriched-type spinel-lherzolite $(\mathrm{P}=17.3-32.5 \mathrm{~kb})$ and for the deleted-type spinel-lherzolite $(\mathrm{P}=$ 16.3-18.3 kb) Chen et al. (2003) suggested that mantle heterogeneity may exist in the Longgang area, Jilin province. Based on major and trace elements and $\mathrm{Sr}-\mathrm{Nd}-\mathrm{Pb}$ isotope data for Cretaceous mafic dikes from the Jiaodong Peninsula, Yang et al. (2004) suggested heterogeneous mantle sources may exist beneath the Jiaodong Peninsula.

$\mathrm{Xu}$ and Bodinier (2004) reported that metasomatism may have occurred after late Mesozoic lithospheric thinning, which marked a dramatic change in lithospheric architecture beneath the Sino-Korean Craton. The $(\mathrm{La} / \mathrm{Yb})_{\mathrm{N}}$ ratios of ultramafic xenoliths in the present study vary from 0.49 to 20.90 indicating mantle heterogeneity in the Panshishan region. The $\mathrm{Sr}-\mathrm{Nd}$ isotopic composition of this study suggested heterogeneous characteristics in the Panshishan region and the influence of different degrees of fluidsmetasomatism on mantle composition (Xia et al. 2013). Lee et al. (2006) pointed out that basaltic rocks from Shandong province may be derived from partial melting of lithospheric mantle (MORBlike) involved a few EM1 components which may be produced by the recent $\mathrm{H}_{2} \mathrm{O}-\mathrm{CO}_{2}$ fluid metasomatism. $\mathrm{H}_{2} \mathrm{O}$ contents of the Cenozoic lithospheric mantle beneath ENCC revealed by mantle xenoliths hosted by alkali basalts (e.g., Penglai, Qixia, Changle, Hebi, Nushan, Panshishan, Lianshan, Fangshan and Beiyan) have been well studied (Yang et al. 2008; Bonadiman et al. 2009; Xia et al. 2010).

The $\mathrm{H}_{2} \mathrm{O}$ contents of clinoproxene, orthopyroxene and whole-rock of peridotite xenoliths hosted by the WECC Cenozoic basalts range from 30 to $654 \mathrm{ppm}, 14$ to $225 \mathrm{ppm}$ and 6 to $262 \mathrm{ppm}$, respectively (Xia et al. 2013). Xia et al. (2013) suggested that the $\mathrm{H}_{2} \mathrm{O}$ contents of the Cenozoic lithospheric mantle represented by peridotite xenoliths fall in a similar range for both WNCC and ENCC. The lower ${ }^{87} \mathrm{Sr} /{ }^{86} \mathrm{Sr}$ and ${ }^{143} \mathrm{Nd} /{ }^{144} \mathrm{Nd}$ ratios, slight LILE enrichment (especially for $\mathrm{Rb}$ and $\mathrm{Ba}$ ) and HFSE depletion observed in the spidergrams (figure 9) suggest that the lithospheric mantle beneath the Panshishan region may have experienced a recent $\mathrm{H}_{2} \mathrm{O}-\mathrm{CO}_{2}$ fluid metasomatism event. The fluidsmetasomatism may cause the enrichment of $\mathrm{Rb}$, $\mathrm{Ba}, \mathrm{U}, \mathrm{Nb}, \mathrm{K}, \mathrm{La}, \mathrm{Ce}, \mathrm{Sr}, \mathrm{P}$ and $\mathrm{Zr}$ contents in ultramafic xenoliths from the Panshishan area.

\section{Conclusions}

According to mineral chemistry and chemical compositions of the ultramafic xenoliths, we suggest that these xenoliths belong to type-I xenoliths consisting of olivine, orthopyroxene, clinopyroxene and spinel. The ultramafic xenoliths have higher $\mathrm{MgO}$ content, but lower $\mathrm{Al}_{2} \mathrm{O}_{3}, \mathrm{TiO}_{2}, \mathrm{CaO}$ and $\mathrm{Na}_{2} \mathrm{O}$ contents than those of primitive mantle proposed by Sun and McDonough (1989), indicating that they may represent residues after different degrees of partial melting from the upper mantle. The $\mathrm{Cr} /(\mathrm{Cr}+\mathrm{Al})$ ratios of spinel and the Fo-values of olivine provide support for the suggestion mentioned above. The enrichment of Rb, Ba, U, Nb, K, $\mathrm{La}, \mathrm{Ce}, \mathrm{Sr}, \mathrm{P}$ and $\mathrm{Zr}$ of ultramafic xenoliths found in Jiangsu province may be related to the $\mathrm{CO}_{2}-$ $\mathrm{H}_{2} \mathrm{O}$-fluids metasomatism. The wider variation of $(\mathrm{La} / \mathrm{Yb})_{\mathrm{N}}$ ratios and incompatible element contents may be due to mantle heterogeneity and fluidmetasomatism in the Panshishan region. On the basis of $\mathrm{Sr}-\mathrm{Nd}$ isotopic ratios, we suggest that the lithospheric mantle beneath the study area mostly belongs to depleted-type mantle but with slightly enriched signatures, indicating the heterogeneous characteristics in the mantle source and the influence of different degrees of fluids-metasomatism on the mantle composition. The equilibrium $\mathrm{P}-\mathrm{T}$ conditions of the spinel lherzolite xenoliths in the study area are: $\mathrm{T}=913 \sim 1045^{\circ} \mathrm{C}, \mathrm{P}=13 \sim 22 \mathrm{~kb}$ corresponding to depths of $45 \sim 83 \mathrm{~km}$. The $\mathrm{P}-\mathrm{T}$ conditions suggest that the geothermal gradient of the upper mantle beneath the study area is approximately similar to oceanic geotherm which may be caused by asthenosphere upwelling. We suggested that lithospheric mantle thinning accompanied by asthenosphere upwelling has occurred and 
a newly accreted and cooled asthenospheric mantle may exist beneath the study area.

\section{Acknowledgements}

The authors would like to thank Dr H J Yang of Department of Earth Sciences, National Cheng Kung University for his kind assistance in Sr and $\mathrm{Nd}$ isotopic composition analyses.

\section{References}

Bence A E and Albee A L 1968 Empirical correction factors for the electron microanalysis of silicates and oxides; J. Geol. 76 382-403.

Bonadiman C, Hao Y T, Coltorti M, Dallai L, Faccini B, Huang Y and Xia Q K 2009 Water contents in pyroxenes from intraplate lithospheric mantle; European J. Mineral. 21 637-647.

Chen D and Peng Z $1985 \mathrm{~K}-\mathrm{Ar}$ ages and $\mathrm{Pb}$ and $\mathrm{Sr}$ isotopic characteristics of Cenozoic volcanic rocks in Shandong, China; Geochimica 5 293-303 (in Chinese).

Chen D G, Chou H T, Yang C T and Wang Y S 1990 Petrogenesis of Cenozoic volcanic rocks and isotopic characteristics of mantle sources in Shandong, Anhwei and Jiangsu provinces. The characteristics and dynamics of upper mantle of China; Seismic Press, Beijing, pp. 124-131 (in Chinese).

Chen S H, O'Reilly S Y, Zhou X H, Griffin W L, Zhang G H, Sun M, Feng J L and Zhang M 2001 Thermal and petrological structure of the lithosphere beneath Hannuoba, Sino-Korean Craton, China: Evidence from xenoliths; Lithos 56 267-301.

Chen J C, Hsu C N and Ho K S 2003 Geochemistry of Cenozoic volcanic rocks and related ultramafic xenoliths from the Jilin and Heilongjiang provinces, northeast China; J. Asian Earth Sci. 21 1069-1084.

Chung S L 1999 Trace element and isotope characteristics of Cenozoic basalts around the Tanlu fault with implications for the eastern plate boundary between north and south China; J. Geol. 107 301-312.

Condie K C, Cox J, O'Reilly S Y, Griffin W L and Kerrich R 2004 Distribution of high field strength and rare earth elements in mantle and lower crustal xenoliths from the southwestern United States: The role of grain-boundary phases; Geochim. Cosmochim. Acta 68 3919-3942.

Dai B Z, Jiang S Y, Jiang Y H, Zhao K D and Liu D Y 2008 Geochronology, geochemistry and $\mathrm{Hf}-\mathrm{Sr}-\mathrm{Nd}$ isotopic compositions of Huziyan mafic xenoliths, southern Hunan Province, south China: Petrogenesis and implications for lower crust evolution; Lithos 102 65-87.

Deng J F, Mo X X, Zhao H L, Wu Z X, Luo Z H and Su S G 2004 A new model for the dynamic evolution of Chinese lithosphere: Continental roots-plume tectonics; Earth-Sci. Rev. 65 223-275.

Dostal J, Zhi X C, Muehlenbachs K, Dupuy C and Zhai M Z 1991 Geochemistry of Cenozoic alkali basaltic lavas from Shandong Province, eastern China; Geochem. J. 25 1-16.

Fabries J 1979 Spinel-olivine geothermometry in periodtites from ultramafic complexes; Contrib. Mineral. Petrol. 69 329-336.

Fan W M, Zhang H F, Baker J, Jarvis K E, Mason P R D and Menzies M A 2000 On and off the North China Craton: Where is the Archaean keel? J. Petrol. 41 933-950.
Gao S, Rudnick R L, Carlson R W, Mcdonough W F and Liu Y S 2002 Re-Os evidence for replacement of ancient mantle lithosphere beneath the North China Craton; Earth Planet. Sci. Lett. 198 307-322.

Griffin W L, O'Reilly S Y and Ryan C G 1992 Composition and thermal structure of the lithosphere beneath south Africa, Siberia and China: Proton microscope studies; Int. Symp. on Cenozoic volcanic rocks and deep-seated xenoliths in China and its environ (Beijing, September 8-10, 1992). Abstr., pp. 65-66.

Griffin W L, Zhang A D, O'Reilly S Y and Ryan C G 1998 Phanerozoic evolution of the lithosphere beneath the Sino-Korean Craton; In: Mantle Dynamics and Plate Interactions in East Asia (eds) Flower M F J, Chung S L, Lo C H and Lee T Y, Am. Geophys. Union Geodyn. Ser. 27 107-126.

Guo F, Fan W, Wang Y and Lin G 2003 Geochemistry of late Mesozoic mafic magmatism in west Shandong Province, eastern China: Characterizing the lost lithospheric mantle beneath the North China Block; Geochem. J. 37 63-77.

Ho K S 1998 Petrology and geochemistry of Cenozoic basalts from southern China; Ph.D. thesis, 580p. (in Chinese).

Huang X L, Xu Y G and Liu D Y 2004 Geochronology, petrology and geochemistry of the granulite xenolith from Nushan, east China: Implication for a heterogeneous lower crust beneath the Sino-Korean Craton; Geochim. Cosmochim. Acta 68 127-149.

Jahn B M 1990 Origin of granulites: Geochemical constraints from archean granulite facies rocks of the Sino-Korean craton, China; In: Granulites and Crustal Evolution (eds) Vielzeuf D and Ph Vidal (Netherlands: Kluwer Academic Publishers), pp. 471-492.

Jahn B M, Auvray B, Cornichet J, Bai Y L, Shen Q H and Liu D Y 19873.5 Ga old amphibolites from eastern Hebei province, China: Field occurrence, petrography, Sm-Nd isochron age and REE geochemistry; Precamb. Res. 34 311-346.

Kempton P D 1987 Mineralogic and geochemical evidence for differing styles of metasomatism in spinel lherzolite xenoliths: Enriched mantle source regions of basalts; In: Mantle Metasomatism (eds) Menzies M and Hawkesworth C J (New York: Academic Press), pp. 45-89.

Kepezhinskas P K, Defant M J and Drummond M S 1995 Sodium metasomatism in the island arc mantle by slab meltperidotite interaction; J. Petrol. 36 1505-1527.

Lee Y T, Chen J C, Shih J Y, Juang W S, Yang H R, Huang S W and Lin M L 2006 Geochemistry of Cenozoic basaltic rocks from Shandong province and its implication for mantle process in North China; Geochem. J. 40 $579-596$.

Li Z X 1994 Collision between the North and South China blocks: A crustal-detachment model for suturing in the region east of the Tanlu fault; Geology 22 739-742.

Liu R X, Chen W J, Sun J Z and Li D M 1992 The K-Ar age and tectonic environment of Cenozoic volcanic rocks in China; In: The Age and Geochemistry of Cenozoic Volcanic Rocks in China (ed.) Liu R X (Beijing: Seismology Publication), pp. 1-43 (in Chinese).

Menzies M A 1983 Mantle ultramafic xenoliths in alkaline magmas: Evidence for mantle heterogeneity modified by magmatac activity; In: Continental Basalts and Mantle Xenoliths (eds) Hawkesworth C J and Norry M J (London: Shiva Publ.), pp. 92-110.

Menzies M A, Fan W M and Zhang M 1993 Paleozoic and Cenozoic lithoprobes and the loss of $>120 \mathrm{~km}$ of Archean lithosphere, Sino-Korean Craton, China; In: Magmatic Processes and Plate Tectonics (eds) Prichard H M, Alabaster T, Harris N B W and Neary C R, Geol. Soc. London Spec. Publ. 76 71-81. 
Menzies M A and Xu X 1998 Geodynamics of the North China Craton; In: Mantle Dynamics and Plate Interactions in East Asia (eds) Flower M F J, Chung S L, Lo C H and Lee T Y, Am. Geophys. Union Geodyn. Ser. 27 167-195.

Mysen B O 1976 Experimental determination of some geochemical parameters relating to conditions of equilibration of periodtite in the upper mantle; Am. Mineral. $61677-683$.

Okay A I and Sengör A M C 1992 Evidence for intracontinental thrust-related exhumation of the ultra-highpressure rocks in China; Geology 20 411-414.

O'Reilly S Y, Griffin W L, Poudjom Y H, Morgan P 2001 Are lithosphere forever? Tracking changes in subcontinental lithospheric mantle though time; GSA Today $114-10$.

Rudnick R L, Gao S, Ling W L, Liu Y S and Mcdonough W F 2004 Petrology and geochemistry of spinel peridotite xenoliths from Hannuoba and Qixia, North China Craton; Lithos 77 609-637.

Smith A D and Huang L Y 1997 The use of extraction chromatographic materials in procedures for the isotopic analysis of neodymium and strontium in rocks by thermal ionisation mass spectrometry; J. National Cheng-Kung University 32 1-10.

Song Y and Fery F A 1989 Geochemistry of peridotite xenoliths in basalt from Hannuoba, eastern China: Implications for subcontinental mantle heterogeneity; Geochim. Cosmochim. Acta 53 97-113.

Stephens W E and Dawson J B 1977 Statistical comparison between pyroxenes from kimberlities and their associated xenoliths; J. Geol. 85 433-449.

Su B X, Zhang H F, Ying J F, Xiao Y and Zhao X M 2009 Nature and processes of the lithospheric mantle beneath the western Qinling: Evidence from deformed peridotitic xenoliths in Ceenozoic kamafugite from Haoti, Gansu Province, China; J. Asian Earth Sci. 34 $258-274$.

Sun S S and McDonough W F 1989 Chemical and isotopic systematics of oceanic basalts: Implications for mantle composition and processes; J. Geol. Soc. London Spec. Publ. 42 313-345.

Tang Y J, Zhang H F and Ying J F 2006 Asthenospherelithospheric mantle interaction in an extensional regime: Implication from the geochemistry of Cenozoic basalts from Taihang Mountains, North China Craton; Chem. Geol. 233 309-327.

Tatsumoto M, Basu A R, Huang W K, Wang J W and Xie G H $1992 \mathrm{Sr}, \mathrm{Nd}$, and Pb isotopes of ultramafic xenoliths in volcanic rocks of eastern China: Enriched components EMI and EMII in subcontinental lithosphere; Earth Planet. Sci. Lett. 113 107-128.

Wang Y, Fan W, Gawood P A and Li S 2008 Sr-Nd-Pb isotopic constraints on multiple domains for Mesozoic mafic rocks beneath the South China Block hinterland; Lithos 106 297-308.

Wilde S A, Zhou X, Nemchin A A and Sun M 2003 Mesozoic crust-mantle interaction beneath the North China Craton: A consequence of the dispersal of Gondwanaland and accretion of Asia; Geology 31 817-820.

Wyllie P J 1981 Plate tectonics and magma genesis; Geol. Rundsch. 70 128-153.

Xia Q K, Hao Y T, Li P, Deloule E, Coltorti M, Dallai L, Yang X Z and Feng M 2010 Low water contents of the Cenozoic lithospheric mantle beneath the eastern part of the North China Craton; J. Geophys. Res. 115 B07207, doi: 10.1029/2009JB006694.

Xia Q K, Hao Y T, Liu S C, Gu X Y and Feng M 2013 Water contents of the Cenozoic lithospheric mantle beneath the western part of the North China Craton: Peridotite xenoliths constraints; Gondwana Res. 23(1) 108-118.

Xu J W 1993 The Tangcheng-Lujiang Wrench Fault System (New York; Wiley), 279p.

$\mathrm{Xu} \mathrm{J}$ and Zhu G 1994 Tectonic models of the Tan-Lu fault zone, eastern China; Int. Geol. Rev. 36 771-784.

Xu Y G 2001 Thermo-tectonic destruction of the Archaean lithospheric keel beneath eastern China: Evidence, timing and mechanism; Physics and Chemistry of the Earth $(A)$ 26 747-757.

Xu Y G 2002 Evidence for crustal components in the mantle and constrains on crustal recycling mechanisms: Pyroxenite xenoliths from Hannuoba, North China; Chem. Geol. 182 301-322.

Xu J W, Zhu G, Tong W, Cui K and Liu Q 1987 Formation and evolution of the Tangcheng-Lujiang wrench fault system: A major shear system to the northeast of the Pacific Ocean; Tectonophys. 134 273-310.

Xu X, O'Reilly S Y, Zhou X and Griffin W L 1998 The nature of the Cenozoic lithosphere at Nushan, eastern China; In: Mantle Dynamics and Plate Interactions in East Asia (eds) Flower M F J, Chung S L, Lo C H and Lee T Y, Am. Geophys. Union Geodyn. Ser. 27 $167-195$.

Xu X S, O'Reilly S Y, Griffin W L and Zhou X 2000 Genesis of young lithospheric mantle in southeastern China: An LAM-ICPMS trace element study; J. Petrol. 41 $111-148$.

$\mathrm{Xu} \mathrm{Y} \mathrm{G} \mathrm{and} \mathrm{Bodinier} \mathrm{J-L} 2004$ Contrasting enrichments in high and low temperature xenoliths from Nushan, Eastern China: Results of a single metasomatic event during lithospheric accretion? J. Petrol. 45 321-341.

Xu Y G, Chung S L, Ma J and Shi L 2004 Contrasting Cenozoic lithospheric evolution and architecture in the western and eastern Sino-Korean craton: Constraints from geochemistry of basalts and mantle xenoliths; J. Geol. 112 593-605.

Yang J H, Chung S L, Zhai M G and Zhou X H 2004 Geochemical and $\mathrm{Sr}-\mathrm{Nd}-\mathrm{Pb}$ isotopic compositions of mafic dikes from the Jiaodong Peninsula, China: Evidence for vein-plus-peridotite melting in the lithospheric mantle; Lithos 73 145-160.

Yang X Z, Xia Q K, Deloule E, Dallai L, Fan Q C and Feng M 2008 Water in minerals of continental lithospheric mantle and overlying lower crust: A comparative study of peridotite and granulite xenoliths from the North China Craton; Chem. Geol. 256 33-45.

Yin A and Nie S Y 1993 An indentation model for the north and south China collision and the development of the Tan-lu and Honam fault systems, eastern Asia; Tectonics 12 801-813.

Ying J F, Zhang $\mathrm{H} \mathrm{F}$, Kita N, Morishita $\mathrm{Y}$ and Shimoda G 2006 Nature and evolution of Late Cretaceous lithospheric mantle beneath the eastern North China Craton: Constraints from petrology and geochemistry of peridotitic xenoliths from Jünan, Shandong Province, China; Earth Planet. Sci. Lett. 244 622-638.

Yuan X 1996 Velocity structure of Qinling lithosphere and mushroom cloud model; Sci. China, Ser. D 39 235244.

Zhang H F 2005 Transformation of lithospheric mantle through peridotite-melt reaction: A case of Sino-Korean Craton; Earth Planet. Sci. Lett. 237 768-780.

Zhang M, Zhou X H and Zhang J B 1998 Nature of the lithospheric mantle beneath NE China: Evidence from potassic volcanic rocks and mantle xenoliths; In: Mantle Dynamics and Plate Interactions in East Asia (eds) Flower M F J, Chung S L, Lo C H and 
Lee T Y, Geodynamics Series, AGU, Washington 27 197-219.

Zhang H H, Xu Y G, Ge W C and Ma J L 2006 Geochemistry of late Mesozoic-Cenozoic basalts in Yitong-Datun area. Jilin Province and its implication; Acta Petrologica Sinica 22 1579-1607.

Zhao D 2001 Seismic structure and origin of hotspots and mantle plumes; Earth Planet. Sci. Lett. 192 251-265.

Zheng Y F, Fu B, Gong B, Feng W M, Li L and Li Y L 2003 Stable isotope geochemistry of ultrahigh pressure metamorphic rocks from the Dabie-Sulu orogenic belt: Implications for geodynamics and fluid regimes; Earth Sci. Rev. 62 105-161.
Zhi X C and Qin X 2004 Re-Os isotope geochemistry of mantle derived peridotite xenoliths from eastern China: Constraints on the age and thinning of lithosphere mantle; Acta Petrol. Sin. 20 989-998 (in Chinese with English abstract).

Zhou X H, Sun M, Zhang G H and Chen S H 2002 Continental crust and lithospheric mantle interaction beneath north China: Isotopic evidence from granulite xenoliths in Hannuoba, Sino-Korean craton; Lithos 62 111-124.

Zou H B, Zindler A, Xu X S and Qi Q 2000 Major, trace element, and $\mathrm{Nd}, \mathrm{Sr}$ and $\mathrm{Pb}$ isotope studies of Cenozoic basalts in SE China: Mantle sources, regional variations, and tectonic significance; Chem. Geol. 171 33-47. 